\title{
Distribution of planktonic cnidarian assemblages in the southern Gulf of Mexico, during autumn
}

\author{
Luis F Martell-Hernández ${ }^{1,2}$, Marina Sánchez-Ramírez ${ }^{1 *}$ and Alberto Ocaña-Luna ${ }^{1}$
}

\begin{abstract}
Background: Despite their ecological, economic and medical relevance, very little information is available on the distribution of planktonic cnidarians, this being particularly true for some regions of the ocean such as the Gulf of Mexico. In fact, the effect of locally important oceanographic features such as the offshore autumnal transport on the distribution of planktonic cnidarians has long been overlooked in this region. Because of this, the present study aimed to analyse the spatial patterns of planktonic cnidarian assemblages in the southern Gulf of Mexico during the autumn of 1998, when particularly intense conditions of convergence, offshore water transportation and productivity were recorded. The assemblages were described in terms of their composition, abundance (volume), diversity, dominance and equitability. Cluster (Bray-Curtis index) and ordination (multidimensional scaling (MDS)) analysis were performed in order to link the observed distribution of species with the environmental parameters.

Results: Sixty-eight taxa were recorded, with Koellikerina fasciculata and Muggiaea atlantica representing new records for the region. The holoplanktonic species Diphyes dispar, Abylopsis spp., Liriope tetraphylla, Diphyes bojani, Aglaura hemistoma, Muggiaea kochi, Chelophyes appendiculata and Eudoxoides mitra were dominant with respect to abundance $\left(\mathrm{ml} / 1000 \mathrm{~m}^{3}\right)$ and frequency of occurrence and defined the differences among the groups of stations. Four groups of sampling stations were identified: (A) the mouth of the Grijalva-Usumacinta system, (B) the Campeche Bank, (C) the area of offshore oil rigs and (D) the continental shelf off Tabasco and associated oceanic waters. The parameters that defined the groups of stations were zooplankton volume, sampling station depth, salinity and dissolved oxygen concentration.

Conclusions: Planktonic cnidarians are useful as indicators of water masses, since the observed zonation was congruent with the surface circulation patterns that are present during the autumn (offshore transportation) and the presence of particular local environmental conditions, including those at the mouth of the Grijalva-Usumacinta system and those associated with the area of oil rigs. We would expect that similar conditions of strong offshore transport would lead to a similar horizontal stratification in the assemblages of planktonic cnidarians in other parts of the world, driven mainly by salinity, oxygen, depth and zooplankton gradients.
\end{abstract}

Keywords: Campeche Bay; Gelatinous zooplankton; Medusae; Siphonophores; Surface circulation

\section{Background}

There is a growing interest worldwide in gelatinous plankton and their various ecosystem roles (e.g. Boero et al. 2008; Richardson et al. 2009), particularly in highly productive areas. The southern Gulf of Mexico constitutes one of such regions, in which a great number of commercial

\footnotetext{
* Correspondence: msanchez@encb.ipn.mx

${ }^{1}$ Laboratorio de Ecología, Departamento de Zoología, Escuela Nacional de Ciencias Biológicas, Instituto Politécnico Nacional, Prolongación de Carpio y Plan de Ayala s/n, Santo Tomás, Miguel Hidalgo, Mexico City C. P. 11340, Mexico

Full list of author information is available at the end of the article
}

fisheries are active (Arenas-Fuentes and Jiménez-Badillo 2004), together with important oil extraction operations (Gold-Bouchot 2004). The surface circulation in this region constitutes an exception to the patterns that are generally observed in the Gulf of Mexico, as it is not under the direct effect of the Loop Current and its associated anticyclonic field, but presents two circulation patterns that are relatively independent one from the other: on the one hand, there is a seasonally changing cyclonic gyre in the offshore waters, with a western boundary current that becomes more intense during autumn-winter and of which the main forcing is the wind stress component

\section{它 Springer}


(Vázquez de la Cerda et al. 2005); on the other hand, the alongshore coastal currents change direction during the same season, generating a convergence and offshore transportation of water masses (Zavala-Hidalgo et al. 2003).

These seasonal variations in the regional circulation patterns are accompanied by important changes in the physicochemical properties of the water that, in turn, are related to changes in the distribution of planktonic organisms. High chlorophyll (phytoplankton) levels have been recorded in areas near the coast, which suggests that there are upwelling phenomena in the eastern region of the Campeche Bank (Merino 1997; Zavala-Hidalgo et al. 2006) and confirms the presence of transportation processes in the southern Campeche Bay (Martínez-López and Zavala-Hidalgo 2009). It has also been suggested that the abundance and distribution of ichthyoplankton are affected by the location of the cyclonic gyre and the input of freshwater from the Grijalva-Usumacinta system (Salas de León et al. 1998), which generates fronts of considerable size in the southern region of the study area (Czitrom et al. 1986). Unfortunately, there is little information on the relationship of these oceanographic conditions and other zooplanktonic organisms, including members of the phylum Cnidaria.

Planktonic cnidarians have a limited mobility and may thus be successfully used as indicators of water masses and their movements (Pagès et al. 2001; Thibault-Botha et al. 2004; Palma and Silva 2006). Knowledge of this group of organisms in the Gulf of Mexico is as yet limited, despite several recent studies that have informed on the relationship between the assemblages of medusae or siphonophores and the local oceanographic conditions (Loman-Ramos et al. 2007; Sanvicente-Añorve et al. 2007a, 2007b, 2009). Considering the intense water mass transportation that takes place in the Campeche
Bay during the autumn-winter, it would be expected that the structure and composition of the planktonic cnidarian assemblages reflect the oceanographic conditions. This hypothesis was explicitly evaluated in this study through the analysis of the medusae and siphonophores collected during an oceanographic cruise that took place in a year in which particularly intense conditions of convergence, offshore water transportation and productivity were recorded in the southern Campeche Bay (MartínezLópez and Zavala-Hidalgo 2009).

\section{Methods \\ Sampling}

Zooplankton samples were collected from November 27 to December 6, 1998, with a Bongo type net, $333 \mu \mathrm{m}$ mesh size, on board the research vessel 'Justo Sierra' of the Universidad Nacional Autónoma de México. Sampling was carried out at 31 stations (Figure 1) located on the continental shelf and slope of the southern Gulf of Mexico, off the Mexican states of Veracruz, Tabasco and Campeche, within a square area limited by $18^{\circ} \mathrm{N}, 95^{\circ} \mathrm{W}$ and $21^{\circ} \mathrm{N}, 91^{\circ} \mathrm{W}$.

Samples were obtained by oblique hauls in a circular trajectory, with a speed of 2 knots and moving $10^{\circ}$ to starboard. The volume of water that was filtered at each station was determined by taking a reading on a flowmeter adapted to the sampling net. The maximum depth sampled varied from 13 to $141 \mathrm{~m}$ and depended on the total depth at each sampling station, which varied from 16 to $2,550 \mathrm{~m}$. The zooplankton samples were preserved immediately after collection with $4 \%$ formalin in sea water that was neutralised with sodium borate.

Apart from collecting biological samples, values were recorded at each station for temperature $\left({ }^{\circ} \mathrm{C}\right)$ and salinity with a CTD probe, $\mathrm{pH}$, turbidity (nephelometric units)

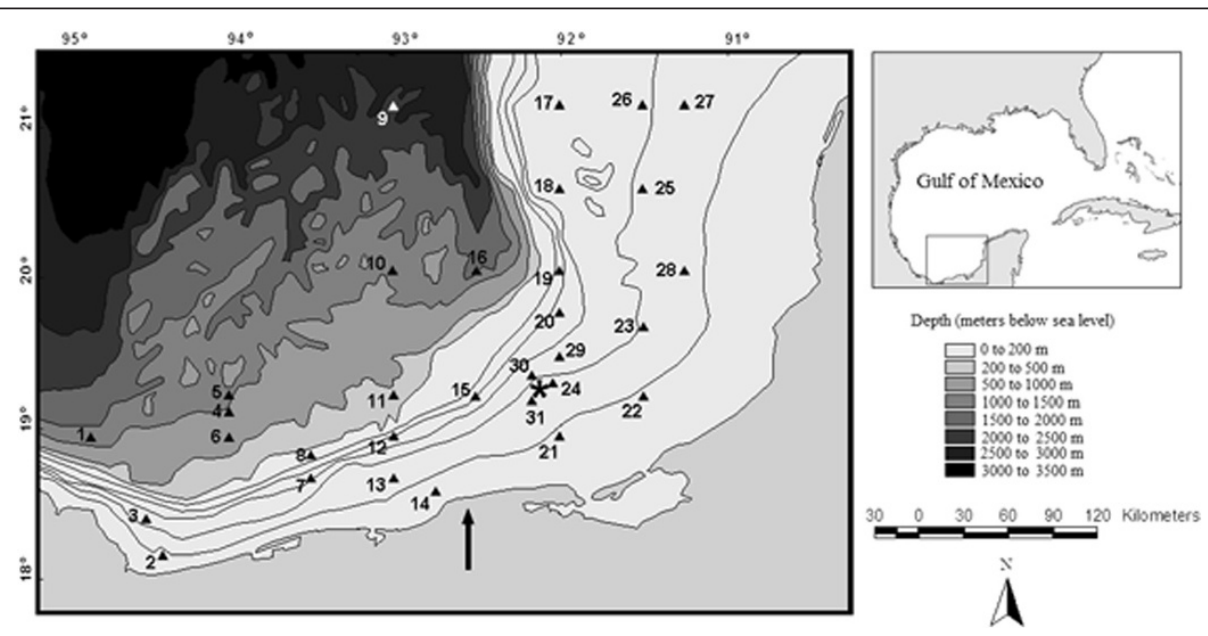

Figure 1 Study area, southern Gulf of Mexico. Sampling stations $(\mathbf{\Lambda})$ and bathymetry. Area of oil rigs $\left(^{*}\right)$. Mouth of the Grijalva-Usumacinta system ( $\uparrow$ ). 
and nitrite, nitrate, silicate, phosphate and dissolved oxygen concentration $\left(\mu \mathrm{mol} \mathrm{L}{ }^{-1}\right)$ in water samples obtained with Niskin bottles at every $10 \mathrm{~m}$ of depth.

\section{Laboratory work}

Planktonic cnidarians were separated from the other organisms collected and were later identified to the lowest possible taxonomic level. Total volume values for zooplankton, planktonic cnidarians and each species were determined for each sampling station following the displacement volume method. The abundance values of medusae and siphonophores were expressed as volume units in order to allow comparison between species. This was necessary as the modular nature of the planktonic cnidarian species makes it impossible to establish a 'number of individuals' for each taxon. Volume was expressed as $\mathrm{ml} / 1,000 \mathrm{~m}^{3}$ in all cases. When a species was present at a sampling station with a volume value smaller than the minimum that could be quantified $(=0.1 \mathrm{ml})$, it was assigned a standard value of $0.05 \mathrm{ml}$ in order to conserve its abundance ratio with respect to the more abundant species (this occurred in $<4 \%$ of the entries of the volume matrix).

\section{Data analyses}

Graphic models for sampling station depth, temperature, salinity, zooplankton volume, $\mathrm{pH}$, turbidity and concentration of nitrates, nitrites, phosphates, silicates and dissolved oxygen were built in order to identify spatial patterns of environmental parameter variations among the sampling stations. The average value of each environmental parameter (except for zooplankton volume and sampling station depth) was calculated for the mixed layer, defined here as the surface water layer in which the difference between the surface temperature and that at the bottom of the layer was less than $0.1^{\circ} \mathrm{C}$. The average parameter values in the mixing layer were then interpolated for the whole study area using the SURFER v8 programme (Golden Software Inc 2002) following the Kriging method.

A principal components analysis (PCA) was applied to the environmental parameter values in order to identify spatial patterns of variation in the study area. To carry out this analysis and considering the differences in the measuring scales associated with each evaluated parameter, the data were previously transformed into the form $\log (x)$, where $x$ represents the average value of each parameter in a given sampling site.

Before performing the statistical analyses, the volume data per sampling station for each species (as a measure of the abundance) were transformed into the form log $(x+1)$, where $x$ represents each individual datum, in order to reduce the extreme disparity in the abundance of the numerically dominant taxa. The importance value index (IVI, modified from Krebs 1985) was calculated for each taxon considering volume and frequency data (number of sampling stations where the analysed taxon was present). The IVI presented a theoretical maximum value of 200 in this study. The species richness, Shannon diversity, equity and dominance indices were also calculated for each sampling station. In all cases, the abundance values corresponded to the volume occupied by each species at each sampling station.

A classification analysis and an ordination analysis were carried out using the transformed abundance values in order to identify spatial patterns of species composition in the study area. The selected similarity index was that of Bray-Curtis. The generated similarity matrix served to obtain a cluster diagram through the hierarchical grouping method and to carry out a non-metric multidimensional scaling (MDS) analysis in order to identify the existing relationships among sampling stations based on biological information. A similarity percentage (SIMPER) routine was applied to determine the taxa that contributed the most to the definition of the identified groups. Finally, the agreement between the spatial patterns suggested by the biological data and by the environmental parameters was evaluated through the BIO-ENV and DistLM routines, the latter of which calculates a multivariate multiple regression analysis of symmetric distance matrices (Anderson 2004). Particularly, the conditional test DistLM FORWARD was used to evaluate the percentage of variability in the cnidarian data that is explained by the set of environmental variables considering the correlations between them. All multivariate analyses were carried out using the PRIMER v6 software (Clarke and Gorley 2006), as suggested by Clarke and Warwick (2001).

\section{Results}

\section{Environmental conditions and zooplankton volume}

The physicochemical values recorded for the water of the mixed layer (approximate thickness $50 \mathrm{~m}$ ) reflect the environmental heterogeneity that is present in the region. However, three areas constantly recorded maximum values for several environmental parameters: the continental shelf of the Campeche Bank (in the eastern region of the study area), the area off the mouth of the Grijalva-Usumacinta system and the middle shelf off Laguna de Términos near the area of oil rigs (Figure 2A,B,D,E,F,G,H). The average temperature in the mixing layer varied from $26.66^{\circ} \mathrm{C}$ to $27.30^{\circ} \mathrm{C}$, the average salinity varied from 33.56 to 36.38 and the zooplankton volume varied from 32.32 to $1,135.47 \mathrm{ml} / 1,000 \mathrm{~m}^{3}$ (Figure $2 \mathrm{C}$ ). The highest values of these parameters were recorded for the eastern region of the study area on the wide continental shelf of the Campeche Bank, with a decrease towards the oceanic area and the continental shelf off Tabasco and Veracruz.

The average values of turbidity and concentration of nitrates and nitrites in the mixing layer were in general 

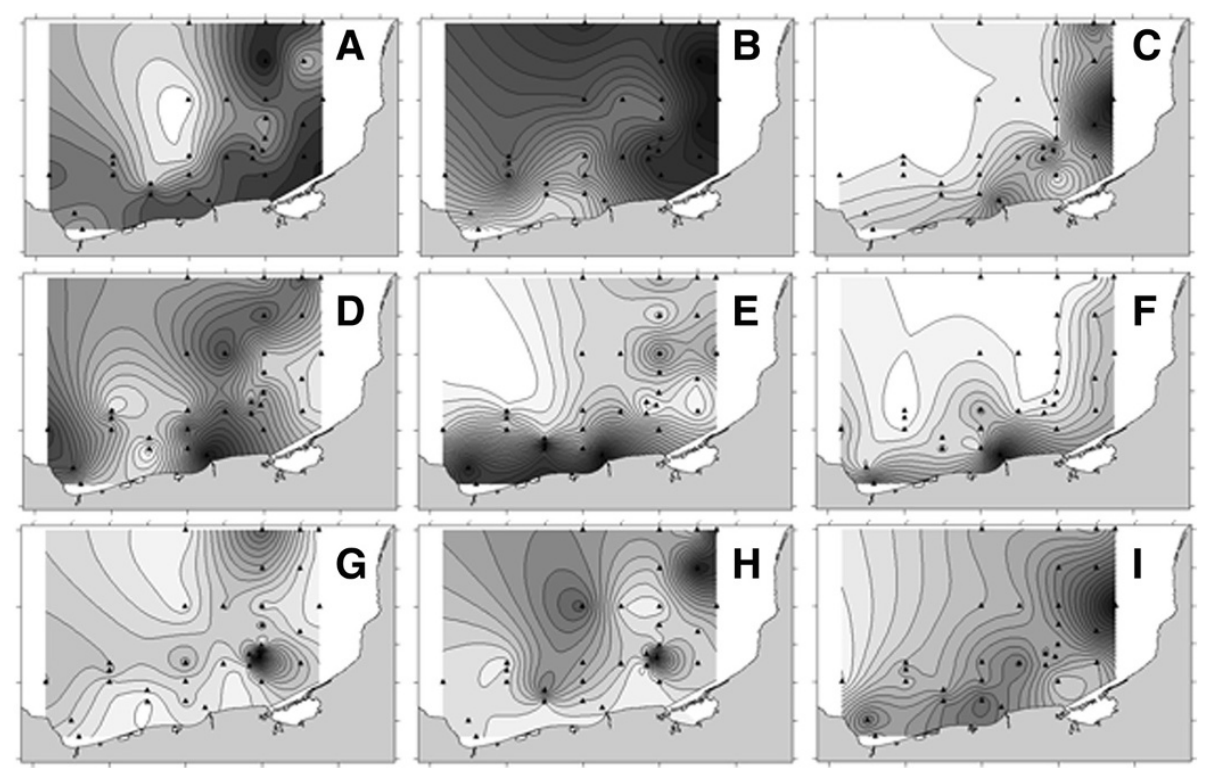

Figure 2 Spatial variation of the average environmental parameters in the mixed layer. (A) temperature, (B) salinity, (C) zooplankton volume, (D) nitrates, (E) nitrites, (F) turbidity, (G) phosphates, (H) silicates and (I) planktonic cnidarians volume. Sampling stations $(\mathbf{\Lambda})$. Range of variation on the colour scales (darker tones represent high values): $26.66^{\circ} \mathrm{C}$ to $27.30^{\circ} \mathrm{C}$ in $\mathrm{A}, 33.56$ to 36.38 in $\mathrm{B}, 32.32$ to $1,135.47 \mathrm{ml} / 1,000 \mathrm{~m}{ }^{3}$ in $\mathrm{C}$, 0.70 to $2.83 \mu \mathrm{mol} \mathrm{L} \mathrm{L}^{-1}$ in $\mathrm{D}, 0.03$ to $0.51 \mu \mathrm{mol} \mathrm{L^{-1 }}$ in $\mathrm{E}, 0.21$ to 1.20 nephelometric units in $\mathrm{F}, 0.94$ to $5.22 \mu \mathrm{mol} \mathrm{L^{-1 }}$ in $\mathrm{G}$, 3.79 to $57.76 \mu \mathrm{mol} \mathrm{L}^{-1}$ in $\mathrm{H}$ and 4.71 to $1,000 \mathrm{ml} / 1,000 \mathrm{~m}^{3}$ in I. Southern Gulf of Mexico. Autumn 1998.

higher off the mouth of the Grijalva-Usumacinta system and lower in the oceanic area and the eastern region of the study area. The average concentration of nitrates varied from 0.70 to $2.83 \mu \mathrm{mol} \mathrm{L} \mathrm{L}^{-1}$ and that of nitrites from 0.03 to $0.51 \mu \mathrm{mol} \mathrm{L}{ }^{-1}$, while turbidity values varied from 0.21 to 1.20 nephelometric units. The average values of phosphates and silicates in the mixing layer varied spatially from 0.94 to $5.22 \mu \mathrm{mol} \mathrm{L}^{-1}$ and from 3.79 to $57.76 \mu \mathrm{mol} \mathrm{L}^{-1}$, respectively. The greatest values for both cases were recorded in the southern Campeche Bank in an area of the middle shelf located off Laguna de Términos where the lowest values of 198.56 to 221.84 $\mu \mathrm{mol} \mathrm{L}{ }^{-1}$ of dissolved oxygen were recorded.

The PCA confirmed the presence of important environmental gradients both in a north-south direction and in an east-west direction in Campeche Bay and allowed groups of stations to be identified in relation to their location with respect to these gradients (Figure 3). The PC1 and PC2 axes explained $73.4 \%$ of the observed variation, with the $\mathrm{PC} 1$ axis explaining $50.7 \%$ of this variation by itself.

In general, the PC1 axis represented an increase in zooplankton volume and a decrease in depth and dissolved oxygen concentration, for which reason the oceanic stations were grouped to the far left of the bidimensional graph and those with greater zooplankton volumes were located mainly towards the right side. The PC2 axis represented, in general, an increase in turbidity and nutrient concentration and a decrease in salinity, for which reason the stations near the southern region of the study area, with the greatest values of nitrites, nitrates and turbidity (e.g. off the Grijalva-Usumacinta system), were grouped in the upper half of the graph and those further away from the coast, with relatively low nutrient and turbidity values and higher salinity values, were located at the far lower left of the graph.

Some groups of stations are evident in the PCA graph, while the boundaries of other groups are less clear. For example, station 14 (off the Grijalva-Usumacinta system) is relatively isolated from the others, while stations 24 , 30 and 31 form a well-defined group of stations on the middle shelf off Laguna de Términos. The stations located in the Campeche Bank and those in oceanic waters formed a more or less compact subgroup, whereas those located on the outer shelf of the Campeche Bank, possibly a transitional area, lie at the centre of the graph.

\section{Planktonic cnidarian assemblages}

In all, 68 taxa of planktonic cnidarians were identified in the study area (Table 1). Of the identified taxa, $44.1 \%$ corresponded to meroplanktonic organisms and 55.9\% were holoplanktonic. It was not possible to identify the species of the genera Obelia and Zanclea, as the characters on which the identification is based are present in the polyp, and not in the medusa stage. Siphonophores belonging to Abylopsis and Amphicaryon were also identified at generic level, as some parts of the colony could not be assigned with certainty to a particular species. 


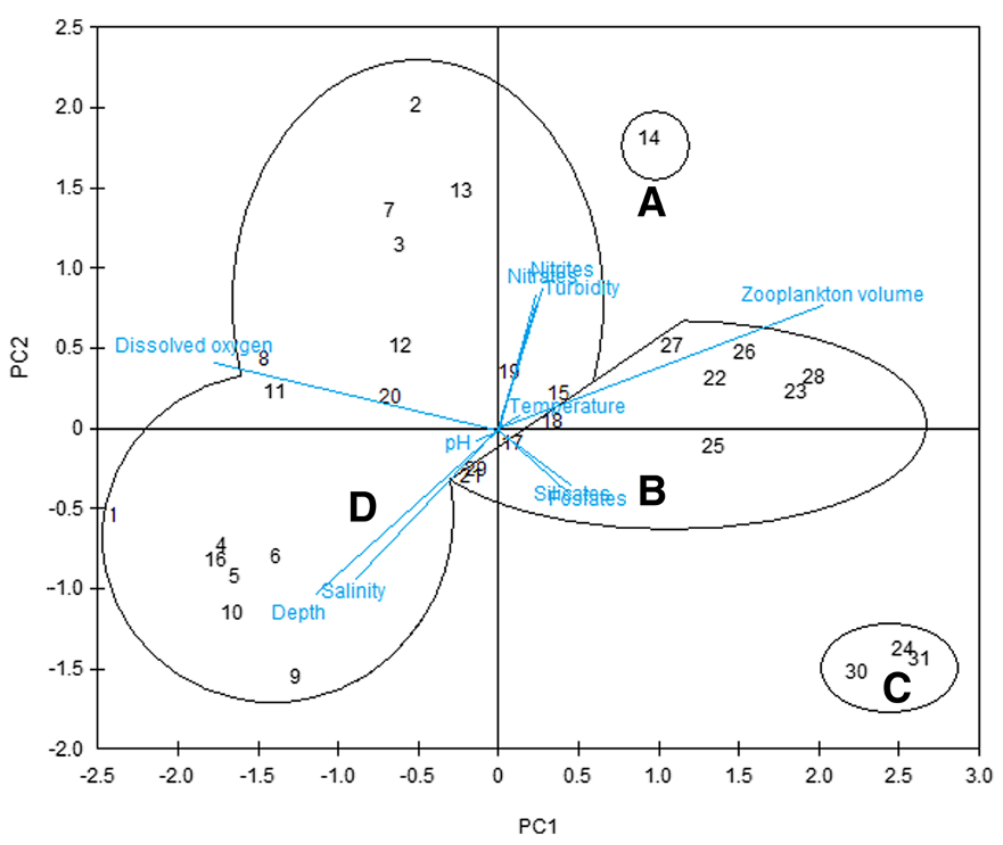

Figure 3 Principal components analysis of the sampling stations based on the environmental parameters. Groups of stations defined by the classification analysis (A to D). Sampling stations (numbers). Southern Gulf of Mexico. Autumn 1998.

However, both Abylopsis tetragona (Otto, 1823) and Abylopsis eschscholtzi (Huxley, 1859) were present in the community, as well as Amphicaryon peltifera (Haeckel, 1888) and Amphicaryon ernesti Totton, 1954.

The volume of planktonic cnidarians per sampling station varied from 4.71 to $1,000 \mathrm{ml} / 1,000 \mathrm{~m}^{3}$. The greatest values were recorded to the east of the study area on the Campeche Bank (Figure 2I).

The volume values per species for a given station varied from $<0.10$ to $967.47 \mathrm{ml} / 1,000 \mathrm{~m}^{3}$. Ten species represented $92.74 \%$ of the total volume of planktonic cnidarians, and with the exception of the meroplanktonic medusae of Eirene pyramidalis, these were exclusively holoplanktonic medusae (Liriope tetraphylla, Aglaura hemistoma) and siphonophores (Diphyes dispar, Nanomia bijuga, Diphyes bojani, Muggiaea kochi, Agalma okeni, Chelophyes appendiculata). All of these species of holoplanktonic cnidarians were also considered dominant community components with IVI values greater than 100 (Table 1), as well as being responsible for the definition of the different groups of stations identified in the classification and ordination analysis (Table 2). In general, the distribution of the abundance values of these species agreed with the groups defined.

The classification analysis of the sampling stations allowed the identification of four groups at a similarity level of $75 \%$ (Figure 4). Groups A, B, C and D were also identified by the ordination analysis (Figure 5), which is an acceptable bidimensional representation of the similarity relationships between sampling stations, as is shown by the level of moderate stress associated with the graph (stress $=0.13$ ). Group A included one single sampling station, station 14, located off the mouth of the GrijalvaUsumacinta system. Group B gathered the stations located on the wide continental shelf of the Campeche Bank, to the east of the study area. Group $\mathrm{C}$ was formed by three stations located on the middle shelf of the southern Campeche Bank, near the area of the Cantarell Complex oil rigs. Group D gathered the other sampling stations, including a subgroup of oceanic stations that was identified both by the classification analysis and the ordination analysis. Group B (Campeche Bank stations) had the greatest values of dominance and volume of planktonic cnidarians, as well as the lowest values of diversity and equity. The opposite occurred in group D that included, among others, the oceanic stations (Table 3).

The ordination analysis of the sampling stations based on the environmental parameters (Figure 3) agreed with the ordination analysis of the same stations based on the species composition and volume data of each observed taxon (Figure 5). The four groups of stations formed by the similarity cluster may be observed in both representations, notwithstanding that the grouping pattern is less evident in the principal components analysis based on the environmental parameters than in the MDS ordination based on the biological data.

The correlation analysis based on the BIO-ENV procedure indicated that the association of environmental parameters that best grouped the sampling stations in agreement with the biological patterns was that integrated by sampling 
Table 1 List of taxa and importance value index (IVI) of the species of planktonic cnidarians

\begin{tabular}{|c|c|}
\hline Taxon & IVI \\
\hline Diphyes dispar Chamisso and Eysenhardt, $1821^{\mathrm{a}}$ & 193.33 \\
\hline Liriope tetraphylla (Chamisso and Eysenhardt, 1821) & 157.92 \\
\hline Diphyes bojani (Eschscholtz, 1829) ${ }^{\mathrm{a}}$ & 134.53 \\
\hline Aglaura hemistoma Péron and Lesueur, $1810^{\mathrm{a}}$ & 132.54 \\
\hline Muggiaea kochi (Will, 1844) ${ }^{\mathrm{a}}$ & 127.11 \\
\hline Chelophyes appendiculata (Eschscholtz, 1829) ${ }^{\mathrm{a}}$ & 115.57 \\
\hline Eudoxoides mitra (Huxley, 1859) ${ }^{\mathrm{a}}$ & 103.12 \\
\hline Abylopsis spp. ${ }^{a}$ & 100.72 \\
\hline Bassia bassensis (Quoy and Gaimard, 1833) ${ }^{\mathrm{a}}$ & 98.25 \\
\hline Nanomia bijuga (delle Chiaje, 1844) ${ }^{a}$ & 95.58 \\
\hline Lensia cossack Totton, $1941^{\mathrm{a}}$ & 90.27 \\
\hline Eudoxoides spiralis (Bigelow, 1911) ${ }^{\mathrm{a}}$ & 87.38 \\
\hline Solmundella bitentaculata (Quoy and Gaimard, 1833) & 85.36 \\
\hline Enneagonum hyalinum Quoy and Gaimard, $1827^{\mathrm{a}}$ & 75.85 \\
\hline Agalma okeni Eschscholtz, $1825^{\mathrm{a}}$ & 74.05 \\
\hline Nausithoe punctata Kölliker, 1853 & 69.41 \\
\hline Rhopalonema velatum Gegenbaur, $1857^{\mathrm{a}}$ & 68.16 \\
\hline Cunina octonaria McCrady, $1857^{\mathrm{a}}$ & 64.41 \\
\hline Sulculeolaria chuni (Lens and van Riemsdijk, 1908) ${ }^{a}$ & 58.78 \\
\hline Lensia hotspur Totton, $1941^{\mathrm{a}}$ & 58.05 \\
\hline Lensia subtilis (Chun, 1886) ${ }^{\mathrm{a}}$ & 53.62 \\
\hline Corymorpha gracilis (Brooks, 1822) & 50.04 \\
\hline Amphicaryon spp. ${ }^{a}$ & 49.35 \\
\hline Eirene pyramidalis (Agassiz, 1862) & 44.33 \\
\hline Zanclea spp. & 39.32 \\
\hline Proboscidactyla ornata (McCrady, 1859) & 39.32 \\
\hline Halitiara formosa Fewkes, 1882 & 32.17 \\
\hline Lensia campanella (Moser, 1917) & 32.17 \\
\hline Lensia meteori (Leloup, 1934) ${ }^{\mathrm{a}}$ & 32.17 \\
\hline Hippopodius hippopus (Forskål, 1776) ${ }^{a}$ & 29.32 \\
\hline Lizzia alvarinoae Segura, 1980 & 25.02 \\
\hline Amphinema dinema (Péron and Lesueur, 1810) & 19.21 \\
\hline Lensia fowleri (Bigelow, 1911) ${ }^{a}$ & 17.87 \\
\hline Persa incolorata McCrady, $1857^{\mathrm{a}}$ & 17.87 \\
\hline Dimophyes arctica (Chun, 1897) ${ }^{a}$ & 15.85 \\
\hline Turritopsis nutricula McCrady, 1857 & 15.64 \\
\hline Bougainvillia muscus (Allman, 1863) & 14.30 \\
\hline Obelia spp. & 14.30 \\
\hline Rosacea cymbiformis (delle Chiaje, 1830) & 11.04 \\
\hline Anthothecata sp. 1 & 10.72 \\
\hline Eucheilota duodecimalis A. Agassiz, 1862 & 10.72 \\
\hline Clytia sp. & 10.72 \\
\hline Sulculeolaria turgida (Gegenbaur, 1853) & 8.07 \\
\hline
\end{tabular}

Table 1 List of taxa and importance value index (IVI) of the species of planktonic cnidarians (Continued)

Sulculeolaria monoica (Chun, 1888) ${ }^{a}$

$\begin{array}{ll}\text { Anthothecata sp. } 2 & 7.15\end{array}$

$\begin{array}{ll}\text { Eirenidae sp. } & 7.15\end{array}$

Eucheilota ventricularis McCrady, $1859 \quad 7.15$

$\begin{array}{ll}\text { Clytia folleata (McCrady, 1859) } & 7.15\end{array}$

Eutima gracilis (Forbes and Goodsir, 1853) 5.18

Bougainvillia platygaster (Haeckel, 1879) 5.03

Clytia hemisphaerica (Linnaeus, 1767) 5.03

Vogtia pentacantha Kölliker, 1853 ${ }^{\mathrm{a}} \quad 4.77$

Koellikerina fasciculata (Péron and Lesueur, 1810) 4.71

Ceratocymba sagittata Quoy and Gaimard, 1827

$\begin{array}{ll}\text { Cladonematidae sp. } & 3.57\end{array}$

Slabberia strangulata (McCrady, 1859) 3.57

Ectopleura dumortierii (Van Beneden, 1844) 3.57

Amphinema rugosum (Mayer, 1900) 3.57

Podocorynoides minima (Trinci, 1903) 3.57

Aequorea macrodactyla (Brandt, 1835) 3.57

Eucheilota paradoxica Mayer, 1900

Clytia discoida (Mayer, 1900) 3.57

Lensia multicristata (Moser, 1925) ${ }^{\mathrm{a}} \quad 3.57$

Muggiaea atlantica Cunningham, 1892

Aegina citrea Eschscholtz, 1829a $\quad 3.57$

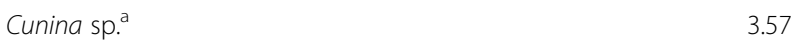

$\begin{array}{ll}\text { Anthothecata sp. } 3 & 3.57\end{array}$

Narcomedusae sp. ${ }^{\text {a }} \quad 3.57$

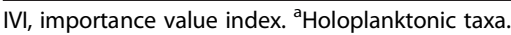

station depth, salinity, dissolved oxygen concentration and zooplankton volume $(\rho=0.641)$. These parameters maximised the correlation of ranges between the dissimilarity matrices of the biological and environmental data and may thus be considered to be the group of parameters that best explained the grouping pattern of the stations observed in the study area. The results of the DistLM analysis showed almost the same set of variables (excluding dissolved oxygen) as strong predictors in the grouping of the cnidarian assemblages (Table 4), together explaining $54.78 \%$ of the cumulative variation.

\section{Discussion}

In general, the values recorded in this study for the physicochemical properties of the water varied within the ranges previously reported for the Gulf of Mexico (Secretaría de Marina 1980; De la Lanza-Espino and Gómez-Rojas 2004). The variations of the surface temperature and salinity coincided in magnitude and spatial distribution with the patterns observed by Loman-Ramos et al. (2007), who recorded the lowest surface temperature and highest 


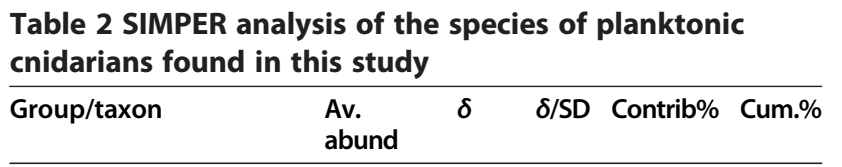

Group A

$\begin{array}{llllll}\begin{array}{l}\text { Only one sampling station (st. 14) } \\ \text { Group B } \\ \text { Average similarity, 70.95 }\end{array} & & & & & \\ \text { Muggiaea kochi } & 8.29 & 18.3 & 1.56 & 45.69 & 45.69 \\ \text { Liriope tetraphylla } & 23.48 & 9.54 & 1.08 & 23.82 & 69.51 \\ \text { Nanomia bijuga } & 15.8 & 4.41 & 0.48 & 11.03 & 80.53 \\ \text { Diphyes dispar } & 3.67 & 2.33 & 0.42 & 5.83 & 86.36 \\ \text { Cunina octonaria } & 1.97 & 2.02 & 0.50 & 5.05 & 91.41\end{array}$

Group C

Average similarity, 83.56

\begin{tabular}{|c|c|c|c|c|c|}
\hline Diphyes dispar & 14.37 & 24.66 & 9.3 & 38.16 & 38.16 \\
\hline Aglaura hemistoma & 7.99 & 18.06 & 8.84 & 27.94 & 66.1 \\
\hline $\begin{array}{c}\text { Chelophyes } \\
\text { appendiculata }\end{array}$ & 2.69 & 4 & 0.65 & 6.19 & 72.29 \\
\hline Bassia bassensis & 1.31 & 3.73 & 0.66 & 5.77 & 78.06 \\
\hline Diphyes bojani & 2.41 & 3.36 & 0.68 & 5.2 & 83.25 \\
\hline Abylopsis spp. & 1.22 & 3.34 & 0.68 & 5.17 & 88.43 \\
\hline Liriope tetraphylla & 1.2 & 3.01 & 0.58 & 4.65 & 93.08 \\
\hline
\end{tabular}

Group D

Average similarity, 64.64

\begin{tabular}{llllll} 
Diphyes dispar & 15.89 & 15.47 & 3.48 & 27.31 & 27.31 \\
$\begin{array}{l}\text { Diphyes bojani } \\
\begin{array}{l}\text { Chelophyes } \\
\text { appendiculata }\end{array}\end{array}$ & 6.80 & 8.95 & 2.39 & 15.80 & 43.11 \\
Abylopsis spp. & 1.14 & 8.24 & 2.52 & 14.54 & 57.65 \\
Eudoxoides mitra & 2.05 & 4.24 & 1.22 & 7.48 & 73.30 \\
Agalma okeni & 3.83 & 3.21 & 0.62 & 5.67 & 78.96 \\
Liriope tetraphylla & 1.17 & 2.85 & 1.58 & 5.02 & 83.99 \\
Bassia bassensis & 0.90 & 1.43 & 0.83 & 2.52 & 86.50 \\
Aglaura hemistoma & 1.60 & 1.34 & 0.65 & 2.36 & 88.86 \\
Rhopalonema velatum & 0.50 & 1.24 & 0.76 & 2.19 & 91.05 \\
\hline
\end{tabular}

Av. abund = average abundance, $\delta=$ average similarity between stations in each group, $\mathrm{SD}=$ standard deviation of $\delta$, Contrib\% $\%$ percentage contribution of each species to $\delta$, Cum.\% = cumulative percentage of contribution to $\delta$, contributors up to a cumulative $90 \%$ for each group are shown.

salinity values in the oceanic area and the highest values of temperature in the shallow area of the Campeche Bank. Surface salinity in the south varies in response to the input of the Grijalva-Usumacinta system, which constitutes the most important contribution of freshwater in the region (Czitrom et al. 1986). The estimated depth of the thermocline was also congruent with previous observations of a mixed layer reaching 40 to $70 \mathrm{~m}$ depth during the summer-autumn (Espinosa-Fuentes and Flores-Coto 2004), with an important vertical mixing process that increases in intensity in winter when it may reach a thickness of up to $100 \mathrm{~m}$ (Alatorre et al. 1989).

The spatial patterns of variation of the zooplankton volume showed the highest secondary productivity values to occur on the Campeche Bank. Individual values of zooplankton biomass and volume recorded by different studies cannot always be compared because of differences in the methods used to estimate them; however, it may be stated that the Campeche Bank is an area of great secondary productivity considering our data as well as those of De la Cruz (1971), Gómez-Aguirre (1987), Flores-Coto et al. (1988), Gasca et al. (1995) and Loman-Ramos et al. (2007). Several factors are related to the abundance of plankton in this area, including the width of the continental shelf and a high diversity of primary producers (Flores-Coto et al. 1988; Okolodkov 2003), as well as the advection of high biomass nuclei generated in upwelling areas (Merino 1997; Zavala-Hidalgo et al. 2006). The relatively high zooplankton volumes located off the mouth of the GrijalvaUsumacinta system are mainly associated with the input of freshwater to this area, confirming that river input variations and coastal circulation patterns have an important effect on the spatial location of high zooplankton biomass nuclei in the region (Salas de León et al. 1998; SanvicenteAñorve et al. 2007b).

Unexpectedly, the PCA analysis showed a lack of neriticoceanic zonation in the study area that differs from previous observations (Salas de León et al. 1998; Flores-Coto et al. 2000; Loman-Ramos et al. 2007), but agrees with the regional circulation patterns of an important offshore transportation during this time of the year following a meeting of the coastal currents in the southern Campeche Bay (Zavala-Hidalgo et al. 2003). The offshore transportation of water masses would then minimise the environmental gradients that are present at other times of the year.

In terms of species composition, the planktonic cnidarian assemblages may be considered typical of the region. All species identified in this study have been previously recorded for the Gulf of Mexico (Segura-Puertas et al. 2009; Pugh and Gasca 2009), with the exception of Koellikerina fasciculata and Muggiaea atlantica. Only recently concern has risen about new records of gelatinous zooplankton in the area, mainly because of the potential ecological and economical consequences, particularly if the new records are those of non-indigenous or invasive species (Graham et al. 2003). Both $K$. fasciculata and M. atlantica are distributed worldwide (Bouillon et al. 2004); thus, more studies are required to determine whether there are established populations in the Gulf of Mexico or if the new records represent recent introductions.

The identified set of dominant species include taxa that have been previously labelled as common and widely distributed in the Gulf of Mexico and adjacent areas (Gasca 


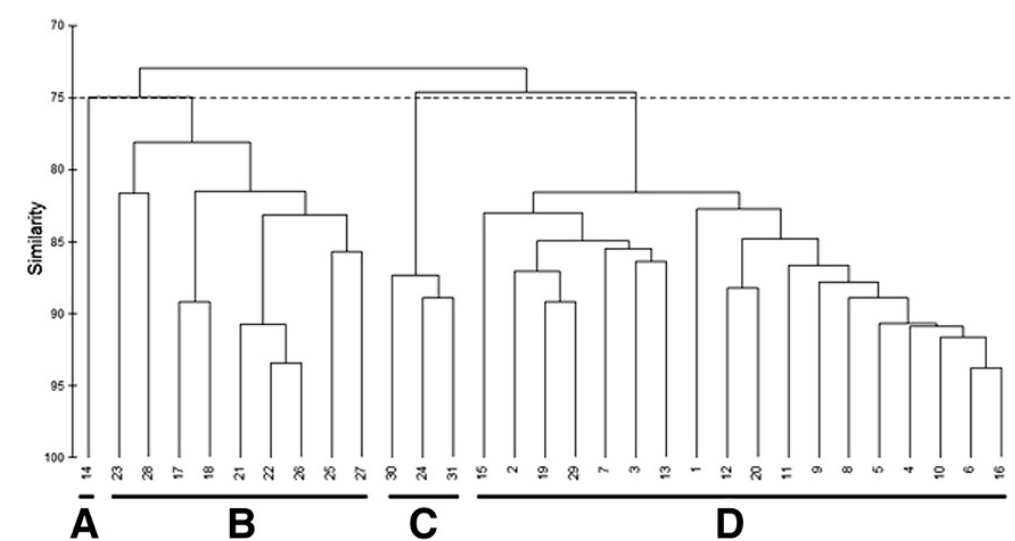

Figure 4 Similarity dendrogram (Bray-Curtis index) of sampling stations. Based on the species composition and the abundance per species $\left(\mathrm{ml} / 1,000 \mathrm{~m}^{3}\right)$ of planktonic cnidarians. Sampling stations (numbers). Southern Gulf of Mexico. Autumn 1998.

1993, 1997, 1998, 1999; Sanvicente-Añorve et al. 2007b; Segura-Puertas et al. 2009; Pugh and Gasca 2009), sometimes being the most abundant component of the gelatinous zooplankton community (Segura-Puertas 1992; Segura-Puertas and Ordóñez-López 1994; Loman-Ramos et al. 2007).

The distribution of the abundance of the planktonic cnidarians observed in this study is also in agreement with previous data (Segura-Puertas and Ordoñez-López 1994; Gasca 1998), since the lowest values were recorded in waters of the Campeche Bank, and the highest values were present in the oceanic area. Spatial patterns of abundance and biomass of planktonic cnidarians are particularly understudied, and only recently, a growing interest in the distribution of jellyfish abundance is developing due to the concern that overfishing may be leading to a proliferation of medusae through fishing down the food web (Lilley et al. 2011; Lucas et al. 2014). To provide a rough comparison of pelagic cnidarian abundance values with those reported by other authors, we estimated the mean biomass (carbon weight, in $\mathrm{mg}$ ) of the assemblages of planktonic cnidarians in the southern Gulf of Mexico. Our results (mean value of $0.63 \pm$ $7.13 \mathrm{mg} \mathrm{C} \mathrm{m}{ }^{3}$ ) fall within the range previously reported for the Northern Atlantic Ocean by Lucas et al. (2014), not being particularly high or low for the region. Needless to say, this value should be taken with caution, since it was based on carbon density data for the tissue of Cladonema californicum medium-sized medusae (see Costello 1998), as density values have not been determined

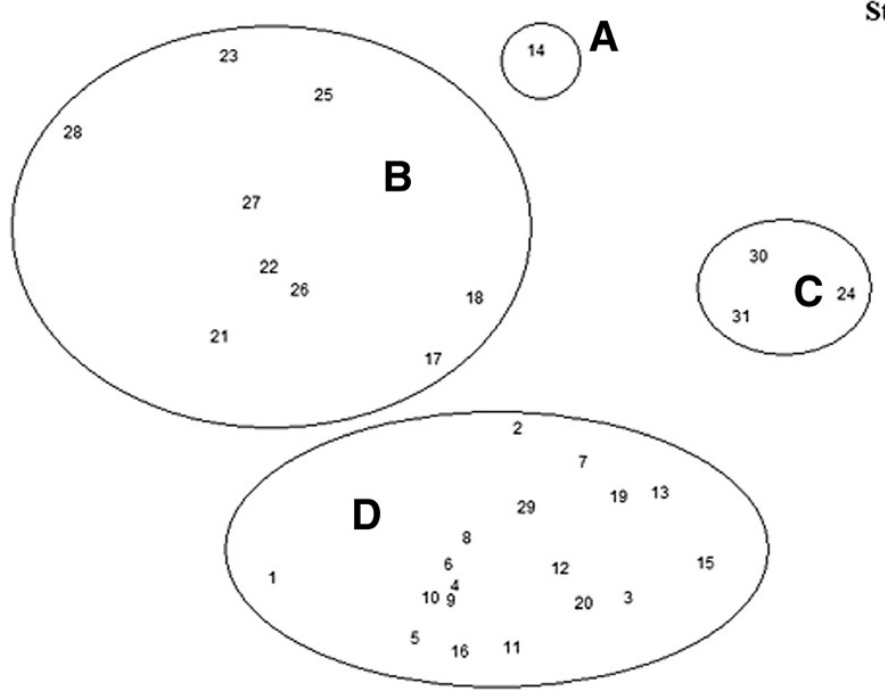

Figure 5 Bidimensional ordination (MDS) of the sampling stations. Based on the species composition and the abundance per species ( $\mathrm{ml} / 1,000 \mathrm{~m}^{3}$ ) of planktonic cnidarians. Sampling stations (numbers). Southern Gulf of Mexico. Autumn 1998. Groups of stations defined by the classification analysis (A to D). 
Table 3 Ecological parameters of the groups of stations identified by the classification and ordination analyses

\begin{tabular}{lllll}
\hline Group of sampling stations & A & B & C & D \\
\hline Planktonic cnidarians volume $\left(\mathrm{ml} / 1,000 \mathrm{~m}^{3}\right)$ & 72.05 & $167.46 \pm 318.05$ & $36.11 \pm 7.21$ & $42.40 \pm 31.83$ \\
Shannon diversity & 1.26 & $0.87 \pm 0.39$ & $1.54 \pm 0.16$ & $1.90 \pm 0.35$ \\
Equity & 0.49 & $0.34 \pm 0.14$ & $0.52 \pm 0.04$ & $0.60 \pm 0.10$ \\
Dominance & 0.40 & $0.56 \pm 0.20$ & $0.27 \pm 0.04$ & $0.21 \pm 0.13$ \\
Number of species & 13 & 37 & 26 & 54
\end{tabular}

for other hydrozoan species. Nevertheless, we believe that this calculation is important since it allows comparison of our results with abundance values observed in other regions of the world's oceans. Further surveys of the area are also much needed, in order to gain insight on long-term changes and inter-annual variability of gelatinous plankton abundance.

The four groups of sampling stations identified in this study were particularly influenced by the distribution of the abundance of the dominant species. These distribution patterns coincided with those observed by LomanRamos et al. (2007) and additionally suggest that the planktonic cnidarian assemblages vary markedly from the coast to deeper waters (offshore variability) in agreement with the observations of Sanvicente-Añorve et al. (2007b).

The spatial distribution of the abundance of planktonic cnidarians and other gelatinous zooplankton organisms is mostly the result of interactions among the biological characteristics (behaviour, ecological tolerance, life cycle aspects, etc.) of each species and the physical parameters of the water (Graham et al. 2001), as may be seen for the assemblages observed here. Several environmental factors have also been pointed out as determining the distribution patterns of planktonic cnidarian populations in other parts of the world. In general, these factors vary in relation to the temporal and spatial scales under study; however, it is possible to say that upwelling phenomena, as well as oceanic gyres, currents, the distance off the coast, the depth of the mixing layer and the effect of freshwater input, have been recognised by various authors (Gasca 1999; Suárez-Morales et al. 2002; ThibaultBotha et al. 2004; Sanvicente-Añorve et al. 2007b) as important factors that determine spatial-temporal changes in planktonic cnidarian assemblages.
Zooplankton volume represents a measure of the amount of food that is available for planktonic cnidarians, and the fact that the total volume of the studied community varies spatially following the variation of zooplankton abundance suggests that the availability of food determines the distribution of the abundance of medusae and siphonophores in the study area. A similar trend was observed by Loman-Ramos et al. (2007) when analysing jellyfish species in the region. This is related to the predatory habits of the planktonic cnidarians, as it has been observed that the spatial distribution of jellyfish and siphonophores coincide in time and space with that of their prey (Purcell 1981, 1997). Depth at each sampling station, on the other hand, reflects the position of the station with respect to the coast, and as such has been previously considered an important parameter for the definition of groups of stations in the Gulf of Mexico (Gasca 1999) and elsewhere (Biggs et al. 1981; Mackie et al. 1987). Salinity has been previously related to the abundance and richness of medusae and siphonophores in several parts of the world (Santhakumari et al. 1999; Thibault-Botha et al. 2004; Zakaria 2004), among them is the Gulf of Mexico (Sanvicente-Añorve et al. 2007b, 2009). Furthermore, the presence of saline fronts is commonly associated with the formation of planktonic cnidarian assemblages (Graham et al. 2001), the same way the patterns observed in the south-eastern Gulf of Mexico suggest that the input of freshwater (mainly from the Grijalva-Usumacinta system) and the salinity gradient it generates are very important factors that determine the dynamics of the zooplankton populations in this region.

Previous investigations (Flores-Coto et al. 2000; Loman-Ramos et al. 2007) had indicated the presence of well-defined groups of neritic and oceanic stations, determined by the composition and abundance of various

Table 4 Best set of environmental variables explaining the variance in biological data

\begin{tabular}{llllllll}
\hline Variable & AIC & SS (trace) & Pseudo F & $\boldsymbol{P}$ value & \% Var & \% Cum & $\boldsymbol{d f}$ \\
\hline Depth of sampling station & 233.27 & 12,259 & 7.1374 & 0.001 & 0.19751 & 0.19751 & 29 \\
Salinity & 231.25 & $6,704.6$ & 4.3553 & 0.005 & $1.32 \mathrm{E}-01$ & 0.32903 & 28 \\
Zooplankton volume & 229.85 & $5,274.5$ & 3.7646 & 0.003 & $2.19 \mathrm{E}-01$ & 0.54767 & 27 \\
\hline
\end{tabular}

DistLM-forward analysis; Akaike Information Criterion $(\mathrm{AIC})=229.85 ; R^{2}=0.5477 ; \mathrm{RSS}=37829 ; 3$ variables. SS (trace) $=$ portion of sum of squares related to the analysed predictor variable, $\% \mathrm{Var}=$ percentage of variance in species data explained by respective variable in the row, $\%$ Cum $=$ cumulative percentage of variance explained, $d f=$ degrees of freedom. 
groups of zooplanktonic organisms. In the present study, however, the observed zonation suggests that the oceanic stations share important similarities with the stations located on the continental shelf. This may be explained considering the surface circulation during the autumn in the study area, particularly the offshore transportation in the southern Campeche Bay (Zavala-Hidalgo et al. 2003) that should tend to homogenise the faunistic composition in the oceanic stations and those on the continental shelf off Tabasco. During 1998, the offshore transportation of water masses was particularly important compared with other years (Martínez-López and Zavala-Hidalgo 2009), and this explains why the stations did not form well-defined neritic and oceanic groups.

\section{Conclusions}

Planktonic cnidarians are useful as indicators of water masses, since the observed zonation was congruent with the surface circulation patterns that are present during the autumn (offshore transportation) and the presence of particular local environmental conditions, including those at the mouth of the Grijalva-Usumacinta system and those associated with the area of oil rigs. We would expect that similar conditions of strong offshore transport would lead to a similar horizontal stratification in the assemblages of planktonic cnidarians in other parts of the world, driven mainly by salinity, oxygen, depth and zooplankton gradients.

\section{Ethical approval}

Ethical approval was not required for this study.

\section{Competing interest}

The authors declare that they have no competing interests.

\section{Authors' contributions}

LFMH performed the taxonomic identification and data analysis and drafted the manuscript. MSR and AOL contributed to the analysis of data. LFMH and MSR wrote the paper. All authors read and approved the final manuscript.

\section{Acknowledgements \\ The authors thank the late F. Vázquez-Gutiérrez, director of the project 'Evaluación prospectiva para el programa de monitoreo continuo del efecto ambiental de la actividad petrolera en el Golfo de México' for providing biological samples and environmental data. Thanks are also due to two anonymous reviewers for constructive feedback on earlier versions of the manuscript. This work was supported by Instituto de Ciencias del Mar y Limnología-Universidad Nacional Autónoma de México, Petróleos Mexicanos (PEMEX), Instituto Politécnico Nacional (Secretaría de Investigación y Posgrado) and the Consejo Nacional de Ciencia y Tecnología (México) [scholarship no. 23009 to LFMH].}

\section{Author details}

${ }^{1}$ Laboratorio de Ecología, Departamento de Zoología, Escuela Nacional de Ciencias Biológicas, Instituto Politécnico Nacional, Prolongación de Carpio y Plan de Ayala s/n, Santo Tomás, Miguel Hidalgo, Mexico City C. P. 11340, Mexico. ${ }^{2}$ Posgrado en Ciencias Biológicas, Universidad Nacional Autónoma de México, Av. Ciudad Universitaria 3000, Coyoacán, Mexico City C. P. 04360, Mexico.
Received: 10 May 2014 Accepted: 12 August 2014

Published online: 14 October 2014

\section{References}

Alatorre MA, Ruiz F, Salas de León DA (1989) Efecto del paso de los frentes fríos atmosféricos sobre la Bahía de Campeche. In: González J, Medina F, Romo M, Martínez M (eds) Memoria de la Reunión Anual 1987. Unión Geofísica Mexicana, México

Anderson MJ (2004) DISTLM v.5: A FORTRAN Computer Program to Calculate a Distance-Based Multivariate Analysis for a Linear Model. Department of Statistics, University of Auckland, New Zealand

Arenas-Fuentes V, Jiménez-Badillo L (2004) Fishing in the Gulf of Mexico: towards greater biomass in exploitation. In: Withers K, Nipper M (eds) Environmental analysis of the Gulf of Mexico. SEMARNAT-INECOL-INE-Harte Research Institute for Gulf of Mexico Studies-Texas A\&M University, Harte Research Institute for Gulf of Mexico Studies Special Publications Series No. 1, Texas

Biggs DC, Bidigare RR, Smith DE (1981) Population density of gelatinous macrozooplankton: in situ estimation in oceanic surface waters. Bio Oceanogr 1:157-173

Boero F, Bouillon J, Gravili C, Miglietta MP, Parsons T, Piraino S (2008) Gelatinous plankton: irregularities rule the world (sometimes). Mar Ecol Prog Ser 356:299-310

Bouillon J, Medel MD, Pagès F, Gili JM, Boero F, Gravili C (2004) Fauna of the Mediterranean hydrozoa. Sci Mar 68:5-438

Clarke KR, Gorley RN (2006) Primer v6: User Manual/Tutorial. PRIMER-E Ltd, Plymouth

Clarke KR, Warwick RM (2001) Changes in marine communities: an approach to statistical analysis and interpretation. PRIMER-E Ltd, Plymouth

Costello J (1998) Physiological response of the hydromedusa Cladonema californicum Hyman (Anthomedusa: Cladonemidae) to starvation and renewed feeding. J Exp Mar Biol Ecol 225:13-28

Czitrom SPR, Ruiz F, Alatorre MA, Padilla AR (1986) Preliminary study of a front in the Bay of Campeche, Mexico. In: Nihoul JCJ (ed) Marine Interfaces Ecohydrodynamics, 1st edn. Elsevier Oceanography Series, Oxford

De la Cruz A (1971) Estudios de plancton en el Banco de Campeche. In: UNESCO (ed) Coloquio sobre investigaciones y recursos del Mar Caribe y regiones adyacentes. UNESCO, Paris

De la Lanza-Espino G, Gómez-Rojas JC (2004) Physical and chemical characteristics of the Gulf of Mexico. In: Withers K, Nipper M (eds) Environmental analysis of the Gulf of Mexico, Firstth edn, SEMARNAT-INECOL-INE-Harte Research Institute for Gulf of Mexico Studies-Texas A\&M University. Harte Research Institute for Gulf of Mexico Studies Special Publications Series No. 1, Texas

Espinosa-Fuentes ML, Flores-Coto C (2004) Cross shelf and vertical structure of ichthyoplankton assemblages in continental shelf waters of the Southern Gulf of Mexico. Estuar Coast Shelf Sci 59:333-352

Flores-Coto C, Martínez-Gutiérrez R, González-Félix M, Sanvicente-Añorve L, Zavala-García F (2000) Annual variation of ichthyoplankton assemblages in neritic waters of the Southern Gulf of Mexico. Caribb J Sci 36:233-243

Flores-Coto C, Sanvicente-Añorve L, Pineda-López R, Rodríguez-van Lier MA (1988) Composición, distribución y abundancia ictioplanctónica del Sur del Golfo de México. Universidad y Ciencia 5:65-84

Gasca R (1993) Especies y abundancia de sifonóforos (Cnidaria: Hydrozoa) en la región sur del Golfo de México. Caribb J Sci 29:220-225

Gasca R (1997) Nuevos registros y ampliación de ámbito de especies de Siphonophora (Cnidaria) en aguas del Atlántico Mexicano. Rev Biol Trop 45:933-934

Gasca R (1998) Siphonophore communities in the southern Gulf of Mexico during April-May, 1986. UNESCO IOC Workshop Report 142:120-126

Gasca R (1999) Siphonophores (Cnidaria) and summer mesoscale features in the Gulf of Mexico. Bull Mar Sci 65:75-89

Gasca R, Suárez-Morales E, Castellanos I (1995) Biomasas zooplanctónicas en aguas superficiales del Golfo de México durante verano e invierno de 1991. Caribb J Sci 31:128-140

Gold-Bouchot G (2004) Hydrocarbons in the southern Gulf of Mexico. In: Withers K, Nipper M (eds) Environmental analysis of the Gulf of Mexico, Firstth edn, SEMARNAT-INECOL-INE-Harte Research Institute for Gulf of Mexico Studies-Texas A\&M University. Harte Research Institute for Gulf of Mexico Studies Special Publications Series No. 1, Texas

Inc GS (2002) Surfer $8^{\circledR}$ User's manual. Golden Software Inc, Colorado 
Gómez-Aguirre S (1987) Biomasa de plancton de la zona económica exclusiva del sureste del Golfo de México y Caribe Mexicano (May-Jul, 1982). Universidad y Ciencia 4:47-54

Graham WM, Martin DL, Felder DL, Asper VL, Perry HM (2003) Ecological and economic implications of a tropical jellyfish invader in the Gulf of Mexico. Biol Invasions 5:53-69

Graham WM, Pagès F, Hamner WM (2001) A physical context for gelatinous zooplankton aggregations: a review. Hydrobiologia 451:199-212

Krebs CJ (1985) Ecology: the experimental analysis of distribution and abundance. Harper and Row, New York

Lilley MKS, Beggs SE, Doyle TK, Hobson VJ, Stromberg KHP, Hays GC (2011) Global patterns of epipelagic gelatinous zooplankton biomass. Mar Biol 158:2429-2436

Loman-Ramos L, Ordoñez-López U, Segura-Puertas L (2007) Variación espacial de la comunidad de medusas (Cnidaria) del sur del Golfo de México, durante el otoño de 1999. Hidrobiológica 17:203-212

Lucas CH, Jones DO, Hollyhead CJ, Condon RH, Duarte CM, Graham WM, Robinson KL, Pitt KA, Schildhauer M, Regetz J (2014) Gelatinous zooplankton biomass in the global oceans: geographic variation and environmental drivers. Global Ecol Biogeogr 23:701-714

Mackie GO, Pugh PR, Purcell JE (1987) Siphonophore biology. Adv Mar Biol 24:97-262

Martínez-López B, Zavala-Hidalgo J (2009) Seasonal and interannual variability of cross-shelf transports of chlorophyll in the Gulf of Mexico. J Mar Syst 77:1-20

Merino M (1997) Upwelling on the Yucatan Shelf: hydrographic evidence. J Mar Syst 13:101-121

Okolodkov YB (2003) A review of Russian plankton research in the Gulf of Mexico and the Caribbean Sea in the 1960-1980s. Hidrobiológica 13:207-221

Pagès F, González HE, Ramón M, Sobarzo M, Gili JM (2001) Gelatinous zooplankton assemblages associated with water masses in the Humboldt Current System, and potential predatory impact by Bassia bassensis (Siphonophora: Calycophorae). Mar Ecol Prog Ser 210:13-24

Palma S, Silva N (2006) Epipelagic siphonophore assemblages associated with water masses along a transect between Chile and Easter Island (eastern South Pacific Ocean). J Plankton Res 28:1143-1151

Pugh PR, Gasca R (2009) Siphonophorae (Cnidaria) of the Gulf of Mexico. In: Felder DL, Camp DK (eds) Gulf of Mexico origins, waters, and biota: volume I, biodiversity. Harte Research Institute for Gulf of Mexico Studies Series, Texas, pp 395-402

Purcell JE (1981) Dietary composition and diel feeding patterns of epipelagic siphonophores. Mar Biol 65:83-90

Purcell JE (1997) Pelagic cnidarians and ctenophores as predators: selective predation, feeding rates and effects on prey populations. Ann Ins Océanogr Paris 73:125-137

Richardson AJ, Bakun A, Hays GC, Gibbons MJ (2009) The jellyfish joyride: causes, consequences and management responses to a more gelatinous future. Trends Ecol Evol 24:312-322

Salas de León DA, Monreal-Gómez MA, Sanvicente-Añorve L, Flores-Coto C (1998) Influence de la circulation à long terme sur la répartition des organismes zooplanctoniques dans la Baie de Campeche, Mexique. Oceanol Acta 21:87-93

Santhakumari V, Tiwari LR, Vijayalakshmi RN (1999) Species composition, abundance and distribution of hydromedusae from Dharamtar estuarine system, adjoining Bombay harbour. Indian J Mar Sci 28:158-162

Sanvicente-Añorve L, Alatorre MA, Flores-Coto C, Alba C (2007a) Relationships between fish larvae and siphonophores in the water column: effect of wind-induced turbulence and thermocline depth. ICES J Mar Sci 64:878-888

Sanvicente-Añorve L, Alba C, Alatorre MA, Flores-Coto C (2007b) Cross-shelf and vertical distribution of siphonophore assemblages under the influence of freshwater outflows in the southern Gulf of Mexico. Hydrobiologia 586:69-78

Sanvicente-Añorve L, Alba C, Flores-Coto C, Castillo-Rivera M (2009) Siphonophores off a riverine system in the southern Gulf of Mexico: factors affecting their distribution and spatial niche breadth and overlap. Aquat Ecol 43:423-435

Secretaría de Marina (1980) Contribución al conocimiento de las características fisicoquímicas de las aguas del Caribe Mexicano: química del océano, 1st edn. Secretaría de Marina, Mexico

Segura-Puertas L (1992) Medusae (Cnidaria) from the Yucatan shelf and Mexican Caribbean. Bull Mar Sci 51:353-359

Segura-Puertas L, Celis L, Chiaverano L (2009) Medusozoans (Cnidaria: Cubozoa, Scyphozoa and Hydrozoa) of the Gulf of Mexico. In: Felder DL, Camp DK (eds) Gulf of Mexico origins, waters, and biota: volume I, biodiversity. Harte Research Institute for Gulf of Mexico Studies Series, Texas, pp 369-379

Segura-Puertas L, Ordoñez-López U (1994) Análisis de la comunidad de medusas (Cnidaria) de la región oriental del Banco de Campeche y el Caribe Mexicano. Caribb J Sci 30:104-115

Suárez-Morales E, Gasca R, Segura-Puertas L, Biggs DC (2002) Planktonic cnidarians in a cold-core ring in the Gulf of Mexico. An Inst Biol Univ Nac Autón Méx Ser Zool 73:19-32

Thibault-Botha D, Lutjeharms JRE, Gibbons MJ (2004) Siphonophore assemblages along the east coast of South Africa; mesoscale distribution and temporal variations. J Plankton Res 26:1115-1128

Vázquez de la Cerda AM, Reid RO, DiMarco SF, Jochens AE (2005) Bay of Campeche circulation: an update. In: Sturges W, Lugo-Fernández A (eds) Circulation in the Gulf of Mexico: observations and models, Firstth edn. American Geophysical Union, Geophysical Monograph Series 161, Washington

Zakaria HY (2004) Pelagic coelenterates in the waters of the western part of the Egyptian Mediterranean Coast during summer and winter. Oceanologia 46:253-268

Zavala-Hidalgo J, Gallegos-García A, Martínez-López B, Morey SL, O’Brien JJ (2006) Seasonal upwelling on the western and southern shelves of the Gulf of Mexico. Ocean Dynam 56:333-338

Zavala-Hidalgo J, Morey SL, O'Brien JJ (2003) Seasonal circulation on the western shelf of the Gulf of Mexico using a high resolution numerical model. J Geophys Res 108:3389, http://dx.doi.org/10.1029/2003JC001879

\section{doi:10.1186/s40693-014-0018-y}

Cite this article as: Martell-Hernández et al:: Distribution of planktonic cnidarian assemblages in the southern Gulf of Mexico, during autumn. Revista Chilena de Historia Natural 2014 87:18.

\section{Submit your manuscript to a SpringerOpen ${ }^{\odot}$ journal and benefit from:}

- Convenient online submission

- Rigorous peer review

- Immediate publication on acceptance

- Open access: articles freely available online

- High visibility within the field

- Retaining the copyright to your article

Submit your next manuscript at $>$ springeropen.com 